\title{
Treponema isoptericolens sp. nov., a novel spirochaete from the hindgut of the termite Incisitermes tabogae
}

Correspondence

Stefan Dröge

stefan.droege@pfi-pirmasens.de

\section{Stefan Dröge, ${ }^{1,2}$ Reinhard Rachel, ${ }^{3}{\text { Renate } \text { Radek }^{4} \text { and Helmut König }}^{1}$}

${ }^{1}$ Institut für Mikrobiologie und Weinforschung, Johannes Gutenberg-Universität Mainz, 55099 Mainz, Germany

${ }^{2}$ Prüf- und Forschungsinstitut Pirmasens eV, 66953 Pirmasens, Germany

${ }^{3}$ Zentrum für Elektronenmikroskopie, NWF III, Biologie und Vkl. Med., Universität Regensburg, 93053 Regensburg, Germany

${ }^{4}$ Institut für Biologie/Zoologie, Freie Universität Berlin, 14195 Berlin, Germany
A novel spirochaete, Treponema sp. strain SPIT5 ${ }^{\top}$, was isolated from hindgut contents of the drywood termite Incisitermes tabogae (Snyder). The cells of strain SPIT5 ${ }^{\top}$ were motile, helical in shape, $0.4-0.5 \mu \mathrm{m}$ in diameter and generally $12-20 \mu \mathrm{m}$ long. The strain is obligately anaerobic and ferments different mono-, di- and oligosaccharides by forming ethanol as the main liquid fermentation end product. Furthermore, strain $\mathrm{SPIT5}^{\top}$ was able to grow anaerobically with yeast extract as sole carbon and energy source. Fastest growth was obtained at $30{ }^{\circ} \mathrm{C}$, the temperature at which the termites were also grown. The optimum $\mathrm{pH}$ for growth was 7.2, with a range of $\mathrm{pH}$ 6.5-8.0. The cells possessed various enzyme activities that are involved in the degradation of lignocellulose in the termite hindgut, such as $\beta$-D-glucosidase, $\alpha-\mathrm{L}$-arabinosidase and $\beta$-Dxylosidase. The $\mathrm{G}+\mathrm{C}$ content of the DNA was $47.7 \mathrm{~mol} \%$. Based on $16 \mathrm{~S}$ rRNA gene sequence analysis, strain SPIT5 ${ }^{\top}$ was shown to belong to the so-called 'termite cluster I' of the genus Treponema. The closest relative of strain SPIT5 ${ }^{\top}$ was Treponema primitia ZAS- $2^{\top}$, with $92.3 \%$ sequence similarity. On the basis of its phenotypic and genotypic properties, strain SPIT5 ${ }^{\top}$ can be distinguished from other described species of the genus Treponema. Therefore, strain SPIT5 ${ }^{\top}$ represents a novel species of Treponema, for which the name Treponema isoptericolens sp. nov. is proposed. The type strain is strain SPIT5 ${ }^{\top}\left(=\right.$ DSM $\left.18056^{\top}=J C M ~ 13955^{\top}\right)$.

\section{Introduction}

The genus Treponema is composed of host-associated, strictly anaerobic or microaerophilic, helical-shaped bacteria which live as symbionts, commensals or parasites in animals and humans (Smibert, 1984). One of the habitats of treponemes is the digestive tract of termites and woodeating cockroaches. The diverse microbial gut community of the termites, consisting of bacteria, archaea, yeasts and unique flagellates, is known to support the decomposition of complex organic compounds and thus enables the termites to feed on wood or soil (Eutick et al., 1978; Breznak \& Brune, 1994; Varma et al., 1994; König et al., 2002; König \& Varma, 2005). Morphologically diverse spirochaetes $(0.2-1.0 \mu \mathrm{m}$ wide and $3-100 \mu \mathrm{m}$ long) are present consistently in the hindgut of all termites (Breznak,

This article is dedicated to the memory of Dr Terry J. Beveridge, who died on 10 September 2007.

The GenBank/EMBL/DDBJ accession number for the 16S rRNA gene sequence of strain SPIT5 $^{\top}$ is $A M 182455$.
1984), and they represent one of the most abundant bacterial groups in the gut (Paster et al., 1996). In the hindgut of the so-called lower termites, spirochaetes have also been found as ectosymbionts attached to the surface of cellulose-digesting protists, which inhabit the digestive tract of these species in great numbers (Cleveland \& Grimstone, 1964; Wenzel et al., 2003).

The evolutionary distance between spirochaetes from termite guts and other members of this group has been clearly demonstrated by several studies based on cultureindependent investigations of $16 \mathrm{~S}$ rRNA gene sequences from different termite guts (Berchtold et al., 1994; Berchtold \& König, 1996; Paster et al., 1996; Ohkuma et al., 1999). Phylogenetic analyses have shown that most symbiotic spirochaetes obtained so far form a distinct branch within the Treponema group of the spirochaetes.

The lack of spirochaetal isolates from termite hindguts has limited our understanding of their physiological properties and thus of their specific role within the symbiotic 
community for many decades. Only a few years ago, the first pure cultures of hindgut spirochaetes were obtained, from the lower termite Zootermopsis angusticollis (Leadbetter et al., 1999; Lilburn et al., 2001; Graber \& Breznak, 2004; Graber et al., 2004). Interestingly, these isolates display physiological pathways that were previously unknown within the spirochaetal group, including acetogenesis from $\mathrm{H}_{2}$ plus $\mathrm{CO}_{2}$ and nitrogen fixation. Both processes are beneficial for termites, because acetate is their major carbon and energy source (Odelson \& Breznak, 1983) and nitrogen fixation by symbiotic hindgut bacteria can supply up to $60 \%$ of the nitrogen in termite biomass (Lilburn et al., 2001). More recently, a novel spirochaete of the genus Spirochaeta was isolated from gut contents of the termite Neotermes castaneus (Dröge et al., 2006). This strain showed different glycolytic activities that are involved in the further breakdown of oligosaccharides derived from cellulose and hemicellulose in the termite gut. These findings imply an important role of symbiotic spirochaetes in the nutrition of the termites. In this study, we describe a novel member of the genus Treponema isolated from the hindgut of the termite Incisitermes tabogae.

\section{Methods}

Strain SPIT5 $^{\mathrm{T}}$ was isolated from hindgut contents of the lower drywood termite Incisitermes tabogae (Snyder) (Isoptera: Kalotermitidae). The termites were obtained from the Federal Institute for Material Research and Testing (BAM, Berlin, Germany). The animals were fed with poplar wood and cultured in metallic vessels containing humid vermiculite at $30{ }^{\circ} \mathrm{C}$. Techniques for the preparation of termite hindguts have been described previously (Dröge et al., 2006). To obtain enrichment cultures, hindgut contents of 10 individuals were transferred into screw-capped tubes containing a modified medium described previously by Leadbetter et al. (1999). The medium contained $\left(1^{-1}\right) 1 \mathrm{~g} \mathrm{NaCl}$, $0.5 \mathrm{~g} \mathrm{KCl}, 0.4 \mathrm{~g} \mathrm{MgCl} .6 \mathrm{H}_{2} \mathrm{O}, 0.1 \mathrm{~g} \mathrm{CaCl}_{2} .2 \mathrm{H}_{2} \mathrm{O}, 0.3 \mathrm{NH}_{4} \mathrm{Cl}, 0.2 \mathrm{~g}$ $\mathrm{KH}_{2} \mathrm{PO}_{4}, 0.15 \mathrm{~g} \mathrm{Na}_{2} \mathrm{SO}_{4}, 2.0 \mathrm{~g}$ peptone, $2.0 \mathrm{~g}$ yeast extract, $5.0 \mathrm{~g} \mathrm{D}-$ glucose and $1 \mathrm{mg}$ resazurin. Aliquots of the basal medium were dispensed in screw-capped tubes and autoclaved. A mixture of nitrogen and $\mathrm{CO}_{2}(80: 20 \mathrm{v} / \mathrm{v})$ was used for the gas phase. Prior to use, the medium was supplemented with the following sterile solutions (per $5 \mathrm{ml}$ ): $0.3 \mathrm{ml} \mathrm{NaHCO} 3(10 \% \mathrm{w} / \mathrm{v}), 0.05 \mathrm{ml}$ trace element solution (tenfold-diluted; Tschech \& Pfennig, 1984), $0.05 \mathrm{ml}$ seven-vitamin solution (tenfold diluted), $0.1 \mathrm{ml}$ cofactor solution (Leadbetter et al., 1999) and $0.05 \mathrm{ml}$ DTT $(0.5 \mathrm{M})$. The tubes were incubated for $2-3$ weeks at $30^{\circ} \mathrm{C}$. Microscopic examination of enrichment cultures showed mainly larger and loosely coiled spirochaetes, whereas smaller and/or tightly coiled morphotypes were rare or absent. The isolated strain SPIT5 ${ }^{\mathrm{T}}$ was obtained by repeated deep-agar dilution series after serial dilution of the enrichment cultures in fresh liquid medium. Visible colonies in deep agar (0.9$1 \% \mathrm{w} / \mathrm{v}$ ) developed after $6-7$ weeks of incubation at $30{ }^{\circ} \mathrm{C}$. No growth was observed in media containing agar concentrations higher than $1 \%(\mathrm{w} / \mathrm{v})$.

The morphology, size range and ultrastructure of the cells were determined by phase-contrast microscopy and transmission electron microscopy (TEM). For TEM, cells were harvested by centrifugation and fixed in a solution of $4 \%$ paraformaldehyde and $2.5 \%$ glutaraldehyde in $0.05 \mathrm{M}$ cacodylate buffer ( $\mathrm{pH} 7.2$ ). After $60 \mathrm{~min}$ incubation, the cells were washed three times in buffer and post-fixed in $2 \% \mathrm{OsO}_{4}$ for $1.5 \mathrm{~h}$. The cells were dehydrated in a series of ethanol and embedded in Spurr's resin. Ultrathin sections were stained with uranyl acetate and lead citrate prior to examination with a Philips CEM 120 Bio-Twin transmission electron microscope.

Utilization of different growth substrates was tested in screw-capped tubes with the medium described above, which was modified according to the carbon source (without glucose, $0.5 \mathrm{~g}$ yeast extract $1^{-1}, 1 \mathrm{~g}$ peptone $1^{-1}$ ). The utilization of carbohydrates and production of fermentation end products were analysed by HPLC (Shimadzu LC 10AD VP) with refractive index detection (RI detector ERC-7515B; Erma CR). Analysis of substrates and fermentation products was performed by using an Aminex HPX $87 \mathrm{H}$ column $(300 \times 7.8 \mathrm{~mm}$; Bio-Rad $)$. The injection volume was $5 \mu \mathrm{l}$, the column temperature was $65{ }^{\circ} \mathrm{C}$ and the flow rate was $0.6 \mathrm{ml} \mathrm{min}{ }^{-1}$. Concentrations of ethanol determined with HPLC were checked by enzyme analysis. Gases were measured with a gas chromatograph (GC 14A; Shimadzu) with a thermal conductive detector and a Sulpelco Carbosieve column (100/120 Carbosieve S-II). Amounts of fermentation products were calculated from the means of three parallel determinations. Growth rates, as well as temperature and $\mathrm{pH}$ optima, were determined by measuring the increase of optical density at $578 \mathrm{~nm}$ by using a spectrophotometer(1101M; Eppendorf). The activities of enzymes that are involved in the degradation of oligosaccharides were tested qualitatively by using nitrophenollabelled carbohydrates (Sigma-Aldrich). Actively growing cells were incubated with the $p$-nitrophenol derivatives (final concentration $0.3 \mathrm{mg} \mathrm{ml}^{-1}$ ) over $24 \mathrm{~h}$. Enzyme activity led to the development of a yellow colour as a result of free nitrophenol in the medium. Negative controls were performed with cell-free medium and with inactivated cells $\left(10 \mathrm{~min}\right.$ at $\left.80^{\circ} \mathrm{C}\right)$.

Genomic DNA was isolated by ethanol precipitation after cell lysis and subsequent phenol/chloroform extraction following a modified Marmur protocol (Johnson, 1991). The bacterial SSU rRNA gene was amplified by PCR using the primers Eubak5 and Eubak3 (Berchtold et al., 1994). The amplified 16S rRNA gene was sequenced commercially (GENterprise). For phylogenetic analysis, the novel $16 \mathrm{~S}$ rRNA gene sequence was added to the ARB database and aligned against existing similar sequences using the fast aligner of the ARB software package (Ludwig et al., 2004). The alignment was checked manually and corrected where necessary. Highly variable regions of the 16S rRNA gene were excluded from the phylogenetic analysis by using only those nucleotide positions that were identical in at least $50 \%$ of all sequences of the alignment. Pairwise distances between taxa were calculated using Kimura's two-parameter model (Kimura, 1980). To determine the evolutionary relationship of the newly isolated organism, the neighbour-joining method (Saitou \& Nei, 1987), included in the PHYLIP 3.5 program package (Felsenstein, 1993), was used. The reliability of the reconstructed tree was evaluated by bootstrap analysis (Felsenstein, 1985).

The $\mathrm{G}+\mathrm{C}$ content of the DNA was determined as described by Mesbah et al. (1989) after degradation of the DNA to nucleosides by P1 nuclease and alkaline phosphatase and subsequent separation of the nucleosides by HPLC.

\section{Results and Discussion}

In deep agar, strain SPIT5 ${ }^{\mathrm{T}}$ formed spheroid white colonies with diffuse edges and a higher density toward the centre (cotton ball-like). Cells of strain SPIT5 ${ }^{\mathrm{T}}$ were highly motile, with wavy or rotating movement. The morphological features of strain SPIT $^{\mathrm{t}}$ are shown in Fig. 1 and are indicated in the species description. The novel isolate grew only under strictly anaerobic conditions and exhibited no 


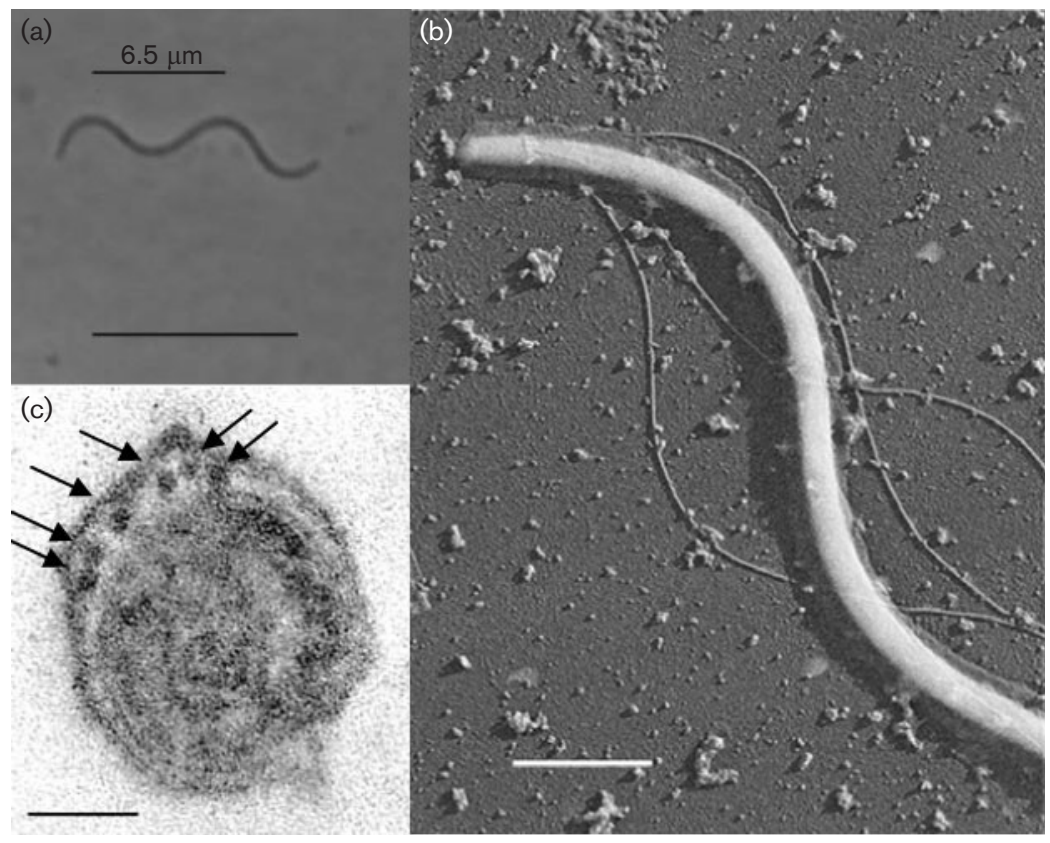

Fig. 1. Morphology of strain SPIT5 ${ }^{\top}$ (Treponema $^{2}$ isoptericolens sp. nov.). (a) Phase-contrast micrograph of a single cell with the wavelength indicated above the cell. Bar, $10 \mu \mathrm{m}$. (b) Scanning electron micrograph of a cell with three flagella released from the periplasmic space. Bar, $1 \mu \mathrm{m}$. (c) Transmission electron micrograph of an ultrathin cross-section shows six flagella in the periplasmic space. Bar, $0.5 \mu \mathrm{m}$.

Table 1. Morphological and physiological properties of strain SPIT5 ${ }^{\top}$ in comparison with other Treponema species

Strains: 1 , SPIT5 ${ }^{\mathrm{T}}$ (Treponema isoptericolens sp. nov.); 2, Treponema primitia ZAS-2 ${ }^{\mathrm{T}}$ (data from Graber et al., 2004); 3, Treponema azotonutricium ZAS-9 ${ }^{\mathrm{T}}$ (Graber et al., 2004); 4, Treponema bryantii DSM $1788^{\mathrm{T}}$ (Stanton \& Canale-Parola, 1980); 5, Treponema saccharophilum DSM $2985^{\mathrm{T}}$ (Paster $^{2}$ \& Canale-Parola, 1985). +, Positive; -, negative; ND, not determined; NR, not reported. All strains produce acetate as an end product of fermentation.

\begin{tabular}{|c|c|c|c|c|c|}
\hline Characteristic & 1 & 2 & 3 & 4 & 5 \\
\hline Cell size $(\mu \mathrm{m})$ & $0.4-0.5 \times 12-20$ & $0.2 \times 3-7$ & $0.2-0.3 \times 10-12$ & $0.3 \times 3-8$ & $0.6-0.7 \times 12-20$ \\
\hline Number of axial filaments & 6 & 2 & 2 & 2 & 32 \\
\hline Optimum temperature $\left({ }^{\circ} \mathrm{C}\right)$ & 30 & 30 & 30 & 37 & $37-39$ \\
\hline \multicolumn{6}{|c|}{ Use as sole carbon source for growth } \\
\hline Arabinose & + & - & - & + & + \\
\hline Xylose & + & + & + & + & - \\
\hline Fructose & + & NR & + & - & + \\
\hline Galactose & - & NR & NR & + & + \\
\hline Glucose & - & + & + & + & + \\
\hline Mannose & - & NR & $\mathrm{NR}$ & + & + \\
\hline Cellobiose & + & - & + & + & + \\
\hline $\mathrm{H}_{2}$ plus $\mathrm{CO}_{2}^{\star}$ & - & + & - & $\mathrm{NR}$ & NR \\
\hline \multicolumn{6}{|l|}{ Fermentation products } \\
\hline Formate & - & - & - & + & + \\
\hline Ethanol & + & - & + & - & + \\
\hline Succinate & - & - & - & + & - \\
\hline $\mathrm{H}_{2}$ & - & - & + & - & - \\
\hline $\mathrm{CO}_{2}$ & + & - & + & - & - \\
\hline DNA G $+\mathrm{C}$ content $(\mathrm{mol} \%)$ & 47.7 & 50.9 & 50 & 36 & 54 \\
\hline
\end{tabular}

${ }^{\star}$ Homoacetogenic growth. 
catalase activity. Strain SPIT5 $^{\mathrm{T}}$ was a chemoheterotroph and showed a fermentative metabolism. Under optimal conditions (with maltose at $30{ }^{\circ} \mathrm{C}$ ), the doubling time of the organism was $45 \mathrm{~h}$. Strain SPIT5 $^{\mathrm{T}}$ required yeast extract (at a minimum concentration of $0.5 \mathrm{~g} \mathrm{l}^{-1}$ ) and a cofactor solution (Leadbetter et al., 1999) for growth. At higher concentrations, yeast extract could serve as a sole carbon and energy source. This was probably a result of the relatively high trehalose content of the yeast extract which was used for cultivation and growth studies. Analysis of yeast extract solutions with trehalase (Sigma) and HPLC revealed a trehalose content of about $85 \mathrm{mg}$ per gram dry powder, resulting in a final concentration of about $0.5 \mathrm{mM}$ trehalose in the medium used for the isolation of strain SPIT5 $^{\mathrm{T}}$ (which contained $2 \mathrm{~g}$ yeast extract $\mathrm{l}^{-1}$ ). Growth of strain SPIT5 ${ }^{\mathrm{T}}$ was improved by the addition of peptone but, in contrast to yeast extract, it could not be used as a sole growth substrate. Further physiological properties are summarized in Table 1.

The di- and oligosaccharide-degrading capacity of strain SPIT5 $^{\mathrm{T}}$ was tested with different nitrophenol-labelled carbohydrates. Strain SPIT5 $^{\mathrm{T}}$ possessed enzyme activities of $\alpha$-L-arabinosidase, $\beta$-D-cellobiosidase, $\beta$-D-fucosidase, $\alpha$ D-galactosidase, $\alpha$-D-glucosidase, $\beta$-D-glucosidase and $\beta$-Dxylosidase. No activities of $\beta$-D-galactosidase, $\beta$-D-glucuronidase or $\alpha$-D-mannosidase were detected. The tested enzyme activities seemed to be cell-bound, because no glycolytic activity was found in the supernatant of the growth medium.

To determine the phylogenetic relationship between the novel isolate and other members of the order Spirochaetales, an almost-complete sequence of the $16 \mathrm{~S}$ rRNA gene was amplified by PCR and sequenced. A comparison with sequences available in GenBank showed that the sequence of strain SPIT5 ${ }^{\mathrm{T}}$ was similar to sequences from the spirochaetal genus Treponema. The highest similarities were observed with molecular clones obtained from hindgut contents of the termite Neotermes koshunensis (about $95 \%$ sequence identity with NkS53, NkS97 and NkS-Oxy3; Noda et al., 2003). The closest relative of strain SPIT5 $^{\mathrm{T}}$ with a validly published name was Treponema primitia ZAS $-2^{\mathrm{T}}$, isolated from hindgut contents of the termite Zootermopsis angusticollis, with $92.3 \%$ sequence similarity. Earlier investigations with culture-independent molecular approaches had shown that the majority of termite spirochaetes belonged to one of the so-called termite clusters I or II of the treponemes (Fig. 2), whereas few could be assigned to the genus Spirochaeta (Dröge et al., 2006). Based on the phylogenetic analysis, strain SPIT5 ${ }^{\mathrm{T}}$ belonged to termite cluster I of the treponemes.

Strain SPIT5 $^{\mathrm{T}}$ was identified as a member of the order Spirochaetales by its phenotypic characteristics. Based on phylogenetic analysis, it could be verified clearly that strain SPIT5 $^{T}$ belonged to the genus Treponema within this bacterial group. The main differences between strain SPIT5 $^{\mathrm{T}}$ and related Treponema species are summarized in

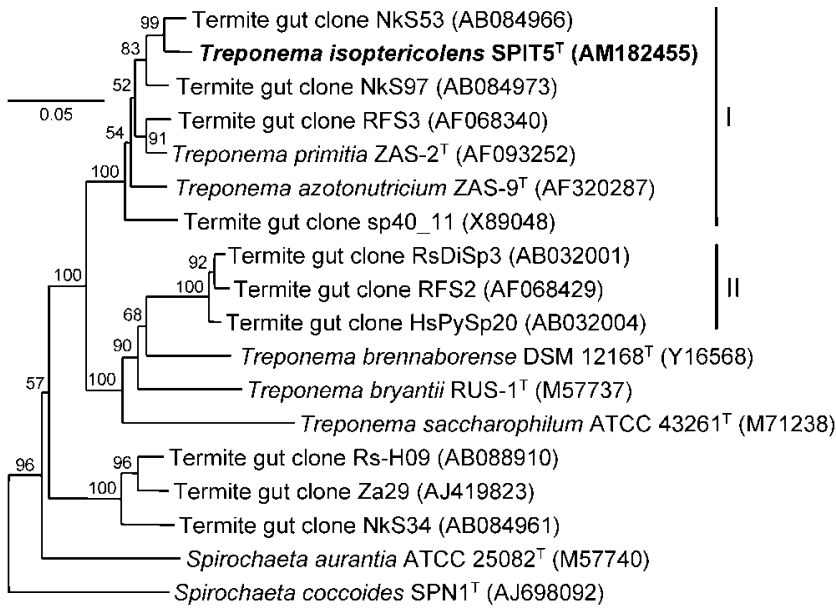

Fig. 2. Phylogenetic tree based on $16 \mathrm{~S}$ rRNA gene sequences showing the relationship of strain SPIT5 ${ }^{\top}$ and other spirochaetes. The tree was constructed by using the neighbour-joining method. Bootstrap values above 50 (from 100 resamplings) are shown for each node. Accession numbers (GenBank) are given in parentheses. Termite clusters I and II of the treponemes are indicated. A sequence of Leptonema illini $3055^{\top}$ (GenBank accession no. Z21632) was used as an outgroup (not shown). Bar, $5 \%$ sequence divergence.

Table 1. Strain $\operatorname{SPIT5}^{\mathrm{T}}$ could be distinguished from its closest relatives in both morphological and physiological characteristics. Strain SPIT5 ${ }^{\mathrm{T}}$ differs from T. primitia ZAS$2^{\mathrm{T}}$ and Treponema azotonutricium ZAS- $9^{\mathrm{T}}$ in cell size and number of axial filaments. Significant differences were also found in important metabolic characteristics, such as the substrate spectra and main fermentation end products. Finally, based on its 16S rRNA gene sequence, strain SPIT5 $^{\mathrm{T}}$ was only distantly related to known species of the genus Treponema ( $>5 \%$ sequence divergence). These results indicated that strain SPIT5 $^{\mathrm{T}}$ represents a novel species of the genus Treponema, for which we propose the name Treponema isoptericolens sp. nov.

\section{Description of Treponema isoptericolens sp. nov.}

Treponema isoptericolens [i.so.pte'ri.co.lens. N.L. pl. neut. n. Isoptera scientific name of an order which encompasses the termites; L. part. adj. colens (from L. v. colere to inhabit) inhabiting; N.L. n. (participial adjective used as a substantive) isoptericolens inhabitant of Isoptera, termites].

Cells are helical-shaped with a wavelength of $6-7 \mu \mathrm{m}$, an amplitude of $1.5-1.8 \mu \mathrm{m}$, a diameter of $0.4-0.5 \mu \mathrm{m}$ and generally $12-20 \mu \mathrm{m}$ in length. Motile by six periplasmic flagella, inserted near opposite ends of the protoplasmic cylinder. Gram-negative. Spherical bodies are formed at the end of the exponential growth phase. Strictly anaerobic and catalase-negative. Yeast extract is required for growth and can serve as a sole energy and carbon source. Optimal temperature for growth is $30{ }^{\circ} \mathrm{C}$. The $\mathrm{pH}$ range for growth 
is $\mathrm{pH}$ 6.5-8.0 with optimum growth at $\mathrm{pH}$ 7.2-7.4. Chemoheterotroph with fermentative metabolism. Grows on arabinose, xylose, fructose, maltose, cellobiose, trehalose, maltotriose and yeast extract. Maltose is fermented to ethanol and $\mathrm{CO}_{2}$ as main fermentation products. Glucose, galactose, lactate, pyruvate, fatty acids, amino acids and polysaccharides are not utilized. Activities of $\alpha$-L-arabinosidase, $\beta$-D-cellobiosidase, $\beta$-D-fucosidase, $\alpha$-D-galactosidase, $\alpha$-D-glucosidase, $\beta$-D-glucosidase and $\beta$-D-xylosidase are exhibited. The $\mathrm{G}+\mathrm{C}$ content of the DNA of the type strain is $47.7 \mathrm{~mol} \%$.

The type strain, $\operatorname{SPIT5}^{\mathrm{T}}\left(=\mathrm{DSM} 18056^{\mathrm{T}}=\mathrm{JCM} 13955^{\mathrm{T}}\right)$, was isolated from hindgut contents of the lower drywood termite Incisitermes tabogae (Snyder) (Isoptera: Kalotermitidae).

\section{Acknowledgements}

We thank Dr Hertel from the Bundesanstalt für Materialprüfung und Materialforschung, Berlin, for supplying us with termite cultures.

\section{References}

Berchtold, M. \& König, H. (1996). Phylogenetic analysis and in situ identification of uncultivated spirochetes from the hindgut of the termite Mastotermes darwiniensis. Syst Appl Microbiol 19, 66-73.

Berchtold, M., Ludwig, W. \& König, H. (1994). 16S rDNA sequence and phylogenetic position of an uncultivated spirochete from the hindgut of the termite Mastotermes darwiniensis Froggatt. FEMS Microbiol Lett 123, 269-274.

Breznak, J. A. (1984). Hindgut spirochetes of termites and Cryptocercus puntulatus. In Bergey's Manual of Systematic Bacteriology, vol. 1, pp. 67-70. Edited by N. R. Krieg \& J. G. Holt. Baltimore: Williams \& Wilkins.

Breznak, J. A. \& Brune, A. (1994). Role of microorganisms in the digestion of lignocellulose by termites. Annu Rev Entomol 39, 453-487.

Cleveland, L. R. \& Grimstone, A. V. (1964). The fine structure of the flagellate Mixotricha paradoxa and its associated micro-organisms. Proc R Soc Lond B Biol Sci 159, 668-686.

Dröge, S., Fröhlich, J., Radek, R. \& König, H. (2006). Spirochaeta coccoides sp. nov., a novel coccoid spirochete from the hindgut of the termite Neotermes castaneus. Appl Environ Microbiol 72, 392-397.

Eutick, M. L., Veivers, P., O'Brian, R. W. \& Slaytor, M. (1978). Dependence of the higher termite Nasutitermes exitiosus and the lower termite Coptotermes lacteus on their hindgut flora. J Insect Physiol 24, 363-368.

Felsenstein, J. (1985). Confidence limits on phylogenies: an approach using the bootstrap. Evolution 39, 783-791.

Felsenstein, J. (1993). PHYLIP (phylogeny inference package) version 3.5. Distributed by the author. Department of Genome Sciences, University of Washington, Seattle, USA.

Graber, J. R. \& Breznak, J. A. (2004). Physiology and nutrition of Treponema primitia, an $\mathrm{H}_{2} / \mathrm{CO}_{2}$-acetogenic spirochete from termite hindguts. Appl Environ Microbiol 70, 1307-1314.

Graber, J. R., Leadbetter, J. R. \& Breznak, J. A. (2004). Description of Treponema azotonutricium sp. nov. and Treponema primitia sp. nov., the first spirochetes isolated from termite guts. Appl Environ Microbiol 70, 1315-1320.
Johnson, J. L. (1991). Isolation and purification of nucleic acids. In Nucleic Acid Techniques in Bacterial Systematics, pp. 1-18. Edited by E. Stackebrandt \& M. Goodfellow. Chichester: Wiley.

Kimura, M. (1980). A simple method for estimating evolutionary rates of base substitutions through comparative studies of nucleotide sequences. J Mol Evol 16, 111-120.

König, H. \& Varma, A. (2005). Intestinal Microorganisms of Termites and Other Invertebrates. Heidelberg: Springer.

König, H., Fröhlich, J., Berchtold, M. \& Wenzel, M. (2002). Diversity and microhabitats of the hindgut flora of termites. Recent Res Dev Microbiol 6, 125-156.

Leadbetter, J. R., Schmidt, T. M., Graber, J. R. \& Breznak, J. A. (1999). Acetogenesis from $\mathrm{H}_{2}$ plus $\mathrm{CO}_{2}$ by spirochetes from termite guts. Science 283, 686-689.

Lilburn, T. G., Kim, K. S., Ostrom, N. E., Byzek, K. R., Leadbetter, J. R. \& Breznak, J. A. (2001). Nitrogen fixation by symbiotic and free-living spirochetes. Science 292, 2495-2498.

Ludwig, W., Strunk, O., Westram, R., Richter, L., Meier, H., Yadhukumar, Buchner, A., Lai, T., Steppi, S. \& other authors (2004). ARB: a software environment for sequence data. Nucleic Acids Res 32, 1363-1371.

Mesbah, M., Premachandran, U. \& Whitman, B. W. (1989). Precise measurement of the $\mathrm{G}+\mathrm{C}$ content of deoxyribonucleic acid by high-performance liquid chromatography. Int J Syst Bacteriol 39, 159-167.

Noda, S., Ohkuma, M., Yamada, A., Hongoh, Y. \& Kudo, T. (2003). Phylogenetic position and in situ identification of ectosymbiotic spirochetes on protists in the termite gut. Appl Environ Microbiol 69, 625-633.

Odelson, D. A. \& Breznak, J. A. (1983). Volatile fatty acid production by the hindgut microbiota of xylophagous termites. Appl Environ Microbiol 45, 1602-1613.

Ohkuma, M., lida, T. \& Kudo, T. (1999). Phylogenetic relationships of symbiotic spirochetes in the gut of diverse termites. FEMS Microbiol Lett 181, 123-129.

Paster, B. J. \& Canale-Parola, E. (1985). Treponema saccharophilum sp. nov., a large pectinolytic spirochete from the bovine rumen. Appl Environ Microbiol 50, 212-219.

Paster, B. J., Dewhirst, F. E., Cooke, S. M., Fussing, V., Poulsen, L. K. \& Breznak, J. A. (1996). Phylogeny of not-yet-cultured spirochetes from termite guts. Appl Environ Microbiol 62, 347-352.

Saitou, N. \& Nei, M. (1987). The neighbor-joining method: a new method for reconstructing phylogenetic trees. Mol Biol Evol 4, 406-425.

Smibert, R. M. (1984). Genus III. Treponema Schaudinn 1905, $1728^{\mathrm{AL}}$. In Bergey's Manual of Systematic Bacteriology, vol. 1, pp. 49-57. Edited by N. R. Krieg \& J. G. Holt. Baltimore: Williams \& Wilkins.

Stanton, T. B. \& Canale-Parola, E. (1980). Treponema bryantii sp. nov., a rumen spirochete that interacts with cellulolytic bacteria. Arch Microbiol 127, 145-156.

Tschech, A. \& Pfennig, N. (1984). Growth yield increase linked to caffeate reduction in Acetobacterium woodii. Arch Microbiol 137, 163-167.

Varma, A., Kolli, B. K., Paul, J., Saxena, S. \& König, H. (1994). Lignocellulose degradation by microorganisms from termite hills and termite guts: a survey on the present state of art. FEMS Microbiol Rev 15, 9-28.

Wenzel, M., Radek, R., Brugerolle, G. \& König, H. (2003). Identification of the ectosymbiotic bacteria of Mixotricha paradoxa involved in movement symbiosis. Eur J Protistol 39, 11-23. 